\title{
Beszámoló a Berend T. Iván 90. születésnapja tiszteletére tartott online konferenciáról
}

2020 decemberében 90. születésnapját ünnepelte Berend T. Iván, korunk egyik legnevesebb magyar társadalomtudósa, a Budapesti Corvinus Egyetem jogelődjének korábbi rektora. A közgazdász és történész végzettséggel is rendelkező professzor mintegy négy évtizeden át tanított egyetemünkön, 1964-től egyetemi tanári rangban. 1967-töl 1986-ig vezette a Gazdaságtörténeti Tanszéket, közben 1973-1979 között az Egyetem rektora volt. 1985-1990 között a Magyar Tudományos Akadémia elnöki tisztségét töltötte be, majd 1990-ben az Egyesült Államokba költözött és 2015-ös nyugdíjba vonulásáig a Kaliforniai Egyetem (UCLA) professzora volt Los Angelesben. Rendkívül termékeny kutatói pályafutásának eredményeit számtalan magyar és angol nyelvü könyvben publikálta - és publikálja mind a mai napig. Nemzetközi elismertségét mutatja az is, hogy számos tudományos társaság választotta tagjai közé (az MTA mellett többek között a Brit Akadémia, az Osztrák Tudományos Akadémia és az Amerikai Müvészeti és Tudományos Akadémia). 1986 és 1994 között a Nemzetközi Gazdaságtörténeti Társaság alelnöke, 1995 és 2000 között pedig a Nemzetközi Történeti Társaság elnöke volt.

A jeles születésnap alkalmából 2020. december 16-án a BCE Gazdaságpolitika és Munkagazdaságtan Tanszéke Ádám Zoltán tanszékvezető szervezésében egy online konferenciát rendezett, hogy így tisztelegjen Berend T. Iván rendkívüli pályafutása előtt. A rendezvény elején Vastag Gyula, a BCE rektorhelyettese köszöntötte a professzort az egyetem nevében, a konferencia fó előadását pedig maga az ünnepelt tartotta. A magyar nyelvű szekcióban emellett köszöntőket és előadásokat hallhattunk Csaba Lászlótól (BCE, CEU), Gyáni Gábortól (ELTE), Győrffy Dórától (BCE, PPKE), Hámori Balázstól (BCE), Ieda Oszamutól (Vaszeda Tudományegyetem), Kövér Györgytől (ELTE), Simonovits Borbálától (ELTE), Surányi Györgytől (BCE) és Szelényi Ivántól (NYU). A konferencia második felét egy angol nyelvü szekció alkotta, ahol felszólalt Andor László (BCE), Grace Ballor (Harvard), Bod Péter Ákos (BCE), Patrice Higonnet (Harvard), Geoffrey Hodgson (Loughborough University), Jürgen Kocka (WZB), Király Júlia (IBS), Mihályi Péter (BCE), Piroska Dóra (BCE, CEU) és Thomas Weber (University of Aberdeen).

Az alábbiakban a konferencián elhangzott köszöntőkből és előadásokból adunk egy rövid válogatást. 


\section{Vastag Gyula köszöntője:}

Kedves Kollégák!

Nagy örömömre szolgál, hogy ilyen rangos résztvevői körben köszönthetem a Professzor Urat, és másodszor is találkozhatom vele, ha csak virtuálisan is. Amit most szeretnék felidézni, az az első találkozásunk emléke, amire nyilván nem emlékszel, de bennem élénken megmaradt. Ez sok-sok évvel ezelőtt történt Budapesten, az egyetem főépületében, ahol konzultációt kértél tőlem és a véleményemet kérdezted néhány késő tizenkilencedik századi magyar gazdaságtörténeti kérdésről. Mielőtt még a munkásságomat ismerők elkezdenek mosolyogni: én akkor sem voltam és azóta sem lettem gazdaságtörténész. Ez az alkalom negyvenöt évvel ezelött történt, 1975. január 14-én, kedd délután, a rektori irodádban, ami most az elnöki irodaként szolgál, és én egy elsőéves hallgató voltam, aki gazdaságtörténetből vizsgázott. Négyest kaptam, és nagyon-nagyon meg voltam elégedve az élménnyel és a végeredménnyel is.

Az a tény, hogy én ezt negyvenöt év távlatából fel tudom idézni, nem az én memóriámat dicséri, hanem sokkal inkább annak elismerése, hogy milyen hatást gyakoroltál, mint kutató, és mint oktató. Most is vissza tudok rá emlékezni, hogy milyen jó beszélgetés volt ez a vizsga. Erre emlékezve, negyvenöt évvel később szeretném megköszönni az élményt, amit nyújtottál személyesen nekem, és azt a munkát, amelyet kutatóként és oktatóként végeztél azóta is a világban és Magyarországon. Isten éltessen, boldog születésnapot kívánok!

\section{Surányi György köszöntője:}

\section{Kedves Iván, kedves Kollégák!}

El kell ismernem, megilletődöttséggel küzdök. Az ünnepi köszöntő nem tartozik az általam legjobban kedvelt műfajok közé, mégis kitüntető megtiszteltetés és különös öröm számomra, hogy többek mellett én is itt lehetek és köszönthetlek. Mindenekelőtt nagyon boldog születésnapot és jó egészséget kívánok!

A kerek évforduló kiváló lehetőség arra, hogy felidézzünk néhány olyan emléket, ami számomra nagyon kedves, és egyúttal bepillantást nyújthat egy olyan világba, amit nagyon nem kedveltünk, de mégis - az olyan kimagasló személyiségeknek köszönhetően, mint amilyen Iván - elviselhető volt, és be kell ismernem, hogy 1968 után, 1989 felé haladva folyamatosan egyre élhetőbbé vált annak ellenére, hogy súlyos ellentmondásokkal volt terhes. Az idő rövidsége miatt három epizódot szeretnék kiemelni.

Az egyik, hogy Iván legendás tanár, legendás előadó volt. Ezt már korábban is tudtam, hiszen az egyik legjobb barátom a mai napig Ránki Zsuzsa, akinek az édesapja Iván egyik legfontosabb munkatársa, kollégája, barátja volt életre szólóan. Emiatt már valamikor a hetvenes évek legelején kezdtem ismerkedni azzal, amit Iván is képviselt. Ezt követően az egyetem polgárává válva, másodévesen találkoztunk elöször személyesen, egy olyan keretrendszerben, ami - azt hiszem - sem akkor, sem ma nem igazán elképzelhető. Iván az Egyetem rektora volt, tanszékvezető egyetemi tanár, akadémikus, és meghirdetett egy alternatív tárgyat Kelet-Közép-Európa gazdaságtörténetéről. Erre hárman jelentkeztünk, és az egyetem rektora minden héten egy délután kollégaként fogadva tulajdonképpen egy elképesztő utazásra vitt minket. Valójában ezek nem is szemináriumok voltak, hanem egy varázslatos utazás a gazdaságtörténet különböző fejezetei között és egy olyan élmény, amelynek keretében Iván valamennyiünket arra inspirált, hogy életünk első szakmai, tudományos (vagy tudományosnak vélt) kutatását megkezdjük. Én ekkor az új gazdaságpolitika, a NEP kapcsán írtam életem első munkáját. Természetesen nagyon célorientált volt, a 
tudományossága megkérdőjelezhető, Iván viszont elképesztő kedvességgel és segítségnyújtással kalauzolt mindannyiunkat, így engem is ennek a munkának az elkészítésében. Azt gondolom, hogy sem a mai világban, sem akkor nem volt könnyen elképzelhető, hogy fiatal emberek ennyi támogatást és segítséget kapjanak egy olyan kiemelkedő személyiségtől, mint Iván.

A következő epizód, amit szeretnék felidézni, 1978-ból való, és talán annak a világnak a hangulatát elég jól ábrázolja. Volt az egyetemnek egy POLVAX nevü klubja, ahova Ivánt rektorként hívták meg. Akkor már végeztem és tanársegéd voltam a Pénzügy Tanszéken. Hihetetlen szabad légkör uralkodott ebben a klubban, mindenki azt mondott és kérdezett, amit óhajtott, annak ellenére, hogy mindenki tisztában volt azzal, hogy a hallgatók között jónéhány besúgó is ül, aki írja a jelentéseket. Az egyik kérdés arra irányult, hogy Berend T. Iván rektornak mi a véleménye arról, hogy Szelényi Ivánt lényegében eltávolították az országból, megfosztották egyetemi katedrájától, így arra kényszerült, hogy elmenjen. Iván a legnagyobb természetességgel közölte a hallgatósággal, hogy nagyon szomorú, nagyon sajnálja, ami történt, kiemelkedő tudósról, szakemberről, oktatóról van szó. A betiltott és akkor már szamizdatban olvasható munkáját, a Konrád Györggyel együtt írt Az értelmiség útja az osztályhatalomhoz című tanulmányt nem betiltani kellene, hanem értelmes vita tárgyává tenni. Azzal fejezte be, hogy Szelényi Iván mindig is a barátja volt és a barátja marad. Azt gondolom, hogy ezt a kiállást 1978-ban még a puha diktatúrában is kevesen tették meg.

Harmadikként 1989-1990-ről szeretnék beszélni, amikor a rendszerváltozás kapujában létrejött egy bizottság, ami pártoktól független, de a pártok által is támogatott hazai és nemzetközi szaktekintélyekböl állt (például Alan Walters, Sylvia Ostry, Béla Balassa, Berend T. Iván, Tardos Márton, Oblath Gábor, Köllő János, olyanok, akiket ma is nagyon magasan jegyzünk). Ez a társaság - azzal együtt, hogy nagyon különböző hátterü, különböző világnézetü emberekből állt - azt a felkérést kapta, hogy fogalmazzon meg egy olyan programot, ami a választásokat követően egyfajta forgatókönyvet adhat az első szabadon választott kormánynak arra, hogy milyen legyen a gazdasági átmenet. Iván - akkor már a Magyar Tudományos Akadémia elnökeként - ebben a munkában is nagyon nagy lelkesedéssel és persze rengeteg kontribúcióval vett részt. Nagy élmény volt ez a közös munka. Erre az eseményre készülve újra belelapoztam: nem kell szégyellnünk, amit akkor leírtunk, a mai napig releváns.

Azzal szeretném befejezni, hogy nagyon szomorúak voltunk, amikor Iván úgy döntött 1990-ben, hogy elhagyja az országot. Az ür betölthetetlen, annak ellenére is, hogy az elmúlt évtizedekben ha lehet, még a korábbinál is nagyobb hozzájárulást tett az egyetemes gazdaságtörténethez. Ezt is köszönjük és nagyon jó egészséget, boldog születésnapot kívánok!

\section{Szelényi Iván köszöntője:}

Kedves Kollégák!

Mindenekelőtt nagyon boldog születésnapot kívánok Ivánnak, és szeretném elmondani, hogy mennyi mindenért vagyok hálás neki. Az idő szükös, de röviden kiemelnék néhány dolgot.

\footnotetext{
${ }^{1}$ Az Éghajlat Kiadó kérésére Berend T. Iván Élj érdekes időkben című könyvéhez Utószót írtam. Az Éghajlat és a Mozgó Világ közös megegyezésével az Utószó egy hónappal a könyv megjelenése elött megjelent a Mozgó Világ 2020. novemberi számában. Sajnos a könyvben magában a kiadó mondandóm lényegét érintő változtatásokat tett megkérdezésem és engedélyem nélkül, ezért ha valaki az Utószóra kívánna hivatkozni, tegye ezt a Mozgó Világban megjelent szöveggel. A könyvben megjelent változatot nem tudom sajátomként elfogadni.
} 
Ott kezdeném, hogy a Marx Károly Közgazdaságtudományi Egyetem, ahova 1956-ban bekerültem, se Marxot, se közgazdaság-tudományt nem tanított. Volt azonban egy fantasztikus tanszék Pach Zsigmond Pállal és Berend T. Ivánnal, akik tudták, hogy hogyan kell társadalomtudományt tanítani. Iván már 1953 óta ott volt a tanszéken, én 1956-ban kerültem oda hallgatóként, és felejthetetlen élmény számomra, hogy Pach Zsigmond Pállal, Berend T. Ivánnal és Ránki Györggyel megtanulhattam valamit arról, hogy mit is jelent az, hogy társadalomtudományi kutatás. Ez egészen rendkívüli dolog volt az 1950-es, 1960-as években.

Ivánnal a későbbiekben is nagyon jó kapcsolatban voltunk, bár csak egy tanítványa voltam, emlékezett rám, amikor ő már Kossuth-díjas, nagy tudós volt. Többször együtt vacsoráztunk - hol náluk, hol nálunk és ez nekem nagyon jólesett.

Később mindenféle bajba keveredtem, 1974-ben egy kis ideig még „vendégül is láttak” a Gyorskocsi utcában egy könyvünk kapcsán, amelynek tartalmáról többet szeretett volna megtudni a III/III., így egy „Szemináriumot” tartottam nekik. Ezt követően senki nem hívott, senki nem keresett, míg egyszer csak csöngött a telefon, és Berend T. Iván volt a vonalban, aki akkor már az egyetem rektora volt. Nemcsak felhívott, hanem elhívott magukhoz vacsorázni. Nagyon kellemesen töltöttük az estét, jót vacsoráztunk, majd a vacsora után Iván így szólt: „El kell mondjam, eljött hozzám a személyzetis, hogy idejött a belügyi összekötő, és azt mondta, hogy Téged ki kell rúgni.” Iván erre így reagált a személyzetisnek: „A belügyminiszter nekem nem felettesem, ha valaki utasítást akar nekem adni, az legyen az oktatási miniszter. Nem rúgjuk ki.” Nekem pedig azt mondta: „Ne gyere be az Egyetemre, amíg nem kapod meg az útleveled Angliába, addig fizetjük a fizetésedet." Azt gondolom, nem sok rektor volt Magyarországon, aki így reagált volna egy belügyes üzenetre.

Az 1980-as években hazaengedtek, de kérdéses volt, hogy tudunk-e lakást venni. Amikor ezt elmondtam Ivánnak, felhívta a pénzügyminisztert, hogy engedjék meg, hogy lakást vegyek. Meg is történt. Iván tehát életem során nagyon sokszor hihetetlen segítséget jelentett nekem. Arról nem is beszélve, hogy vajon lett volna belőlem akadémikus, ha 1990-ben nem Berend T. Iván az Akadémia elnöke? Az a gyanúm, hogy nem.

Ezúton is szeretném megköszönni Ivánnak ezt a sok jót, a barátságát, mindazt, amit tett értem.

\section{Andor László köszöntője:}

\section{Kedves Iván!}

Boldog születésnapot kívánok! Nagyon örülök, hogy láthatlak, és hadd mondjak ötszörösen köszönetet azok nevében, akik az 1980-as években az előadásaidat hallgatták.

Először is iskolateremtő munkádért mondok köszönetet. Ugyanis nem „magányos farkas” voltál gazdaságtörténészként. Már jóval azelőtt, hogy egyetemi hallgatók lettünk, ismertük azt az iskolát, amit Pach Zsigmond Pállal és Ránki Györggyel megteremtettetek. Ez rendkívüli hozzájárulás volt nemcsak az Egyetem humán tőkéjéhez, hanem általában a magyar társadalomtudományhoz is. Nem én voltam az egyetlen, akinek már középiskolásként sokat jelentettek a könyveid és a televízióban látható előadásaid, amelyek aztán a történettudományi érdeklődés és az MKKE felé is tereltek. Külön kiemelném Válságos évtizedek címü könyvedet a két világháború közötti Európáról, ami a fiatal generáció számára nagyszerü bevezetésként szolgált nemcsak az időszak gazdaságstatisztikai adataiba, hanem a mủvészetekbe, valamint a gazdasági, társadalmi és politikai folyamatok összefüggéseibe is. Ez a megközelítés már akkor is egy különleges értéknek számított, az azóta eltelt idő tükrében pedig egyedinek nevezhető. 
A második köszönet az egyetem újjáépítéséért jár. Itt nem csak arról kell beszélni, hogy a rektori időszakodban indított reform újabb lendületet adott a tananyag korszerüsítéséhez, és erős alapot jelentett az egyetem további fejlödéséhez. Egyébként ez a reform hozta létre az egységes alapozó évet (a szakválasztást megelőzendő), amely engem is fogadott 1985-ben. Újjáépítésen azonban az egyetem épületének fizikai megújítását is értem. Rektorságod idejére már veszélyessé vált az épület állapota, ezért elindítottad a teljes rekonstrukciót. Ez egyébként azt is jelentette, hogy a mi évfolyamunknak a Müegyetemre kellett átjárnia az előadásaidat hallgatni a Főépület helyett - ekkoriban ugyanis teljes gőzzel haladt a felújítási folyamat.

Harmadikként azért szeretnék köszönetet mondani, hogy tanárként mindig nagyon közvetlen és barátságos voltál a diákokkal. Példaként azt említeném, amikor diákrektor-választást tartottunk (1986 tavaszán), nagyon kedvesen meghívtad a jelöltünket az akadémiai irodádba. Videoklip is készült róla, ami természetesen nagy sikert aratott az egyetemen. Nem hiszem, hogy sok MTA-elnök vállalt volna hasonlót.

Negyedszer azért mondok köszönetet, mert valóban tanítottál és nem csak előadásokat tartottál. Alapvetően meghatározó volt, hogy nemcsak a tananyagot akartad átadni, hanem a világról alkotott képünket is igyekezted formálni. Akár olyan finom eszközökkel, mint hogy említésszerủen felhívtad a figyelmünket olyan szerzőkre is, akik nem voltak részei a formális tananyagnak. Másképp nem hallottunk volna többek között Fernand Braudelről, Marc Blochról, Arnold Toynbee-ról, vagy akár Jánossy Ferencről. Ezzel bizonyos értelemben kifejlesztettél bennünk egy történetfilozófiai megközelítést, ami mindvégig velünk maradt az egyetemi tanulmányok során, annak ellenére, hogy gazdaságtörténetet csak egy évig tanultunk.

Végezetül, ötödikként az Európai Unió érdemeinek (sosem kritikátlan) hangsúlyozásáért szeretném kifejezni köszönetemet. Hadd említsem meg itt egy olyan könyvedet, ami akkor jelent meg, amikor én uniós biztosként dolgoztam Brüsszelben. A könyv címe Europe in Crisis: Bolt from the Blue? - így, kérdőjellel. Ez egy nagyon fontos könyv volt a kortárs történelemről, és ebben a szociális Európa kérdését is tárgyaltad. Itt is kérdőjellel: fennmaradhat-e a szociális Európa? Történészként erre nem fogalmaztál meg elörejelzést, de ahogy megközelítetted az európai válság, illetve a szociális Európa témáját, az rendkívül hasznos volt a válság időszakában. Hozzájárult ahhoz, hogy egy olyan kilábalási stratégiát fogalmazzunk meg az Európai Unió számára, amely nem nélkülözi az erős szociális dimenziót.

Köszönöm mindezeket, a kollégáknak pedig nagyon jó ünnepi konferenciát kívánok!

\section{Berend T. Iván elöadása:}

Drága Barátaim!

Hadd kezdjem azzal, hogy nem lesz most könnyü beszélnem. Nem vagyok egy sírós öregember, de amiket elmondtatok, mélyen meghatott. Köszönök mindent, köszönöm barátságotokat, köszönöm, hogy ott ültetek az I. előadóban, amikor előadást tartottam, köszönöm, hogy vagytok, és hogy azóta is kapcsolatban vagyunk egymással. Azzal, amit elmondtatok, amit elindítottatok bennem, hazahoztatok. Harminc év után és tízezer kilométeres távolság ellenére ott vagyok az egyetemen, ahova 19 évesen elsőévesként beléptem, ahol már másodéves koromtól alkalmazásban álltam tanszéki könyvtárosként, ahol tanársegéd, tanár, dékán, rektor lettem, ahol majdnem negyven évet tanítottam. Otthon vagyok, ott vagyok Veletek. Nagyon köszönöm ezt a mai napot Nektek!

Előadásom Az európai integráció gazdasági előnye címet viseli. Ez egy nagyobb tanulmány vázlata, ami majd egy hollandok által szerkesztett kötetben fog megjelenni egy vagy két hónap múlva a Cambridge University Pressnél. 
Azzal kezdem, hogy hogyan állt az európai gazdaság az integráció megindulása, az 1950-es évek előtt. Felidézhetjük, hogy a 19. század közepén, sőt, majdhogynem utolsó harmadáig Európa volt a világgazdaság vezető hatalma, 1870-ben is majdnem felét állította elő a világ összes jövedelmének. Ezt követően viszont elindult egy elég gyors relatív visszaesés a tengerentúlhoz (Amerika, Ausztrália, Új-Zéland stb.) képest, és 1913-ban Európa már csak alig több mint negyedét produkálta a világ össztermelésének. Az Egyesült Államokhoz viszonyítva: míg az első világháború előtt majdnem az amerikai felét elérte az európai jövedelemszint, addig 1948-ban már csak alig több mint egyharmadát. A legszomorúbbak azok az adatok, amelyek azt mutatják, hogy a második világháború hogyan tette tönkre Európát, megölve a lakosság mintegy tíz százalékát. Számos európai országban (például Ausztria, Franciaország, Németország, Olaszország) mintegy felére esett vissza a gazdasági teljesítmény a háború után az utolsó békeévhez képest.

Ezt követte a rekonstrukció korszaka. A régi értelmezés szerint a rekonstrukciós szakasz addig tart, míg a gazdasági teljesítmény eléri az utolsó békeév szintjét. 1948-ra ez több országban (például Belgium, Dánia, Anglia) megtörtént, noha más országok ekkor még elmaradtak a háború előtti szinttől. Jánossy Ferenc kollégám, barátom az 1960-as években viszont egy teljesen új koncepcióval állt elő a rekonstrukciót illetően, világraszóló sikerrel. Értelmezése szerint a rekonstrukciós szakasz akkor ér véget, amikor a gazdasági teljesítmény eléri azt a szintet, amit a megelőző időszak hosszú távú növekedési tendenciái alapján az adott ország elért volna, ha nincs háború. Ha így fogjuk fel a rekonstrukció fogalmát, akkor az Európában egészében véve csak 1968 körül fejeződött be, vagyis két évtizeddel később. Az egész rekonstrukciós korszak a „gazdasági csoda” időszaka volt, mert egy speciális, gyors, rekonstrukciós növekedés jellemezte.

Ebben a folyamatban azonban már szerepet játszott az európai integráció megindulása. Itt a Marshallterv szerepét szeretném kiemelni, melynek keretében az Egyesült Államok 1948 és 1951 közötti nemzeti jövedelme 5 százalékának ráfordításával 15 milliárd dollár támogatást nyújtott 16 nyugat- és dél-európai országnak. Közismert a Marshall-terv szerepe a helyreállításban. Kevésbé ismert azonban, hogy a Marshallterv fó célja egy európai gazdasági unió létrehozása volt, és ennek érdekében a segély feltételeként kötötték ki a vámok leépítését és egy közös fizetési rendszer (payment union) kiépítését, vagyis a két világháború közötti elzárkózás felszámolását és az integráció megindulását.

A Marshall-tervvel az integráció szerényen elindult, majd 1952-ben az Európai Szén- és Acélközösség létrehozásával megtette az első nagy lépést, 1958-ban pedig már Európai Gazdasági Közösséggé vált, amiben hat alapító ország vett részt, hogy azután a résztvevők száma gyorsan gyarapodjon. Az Európai Unió az előbbi alapokon 1993-ban jött létre és a hat alapítóból egy mára 27 tagú európai integrációs közösség formálódott. Ez hihetetlenül megnövelte a kereskedelmi forgalmat a tagországok között. Már 1973-ra, tehát már az első új belépők előtt a tagországok közötti kereskedelem 10-15-szörösére nőtt a két világháború közötti időszakhoz képest. Egyben megindult a külkereskedelem szerkezeti modernizációja is: a régi formát, amelyben az ipari országok az agrárországokkal cseréltek árut, felváltotta az ipari országok közötti munkamegosztás. Az ipari és agrárországok közötti kereskedelem súlya 33\%-ról 18\%-ra esett vissza. Megindult az ipari kooperáció is, amelynek első, legismertebb példája a repülőgépgyártás (Concorde és Airbus) kollektív megszervezése. Ez egyben az új, modern ipari szektorok növekedését is jelentette. Az európai gazdasági növekedés 3-4-szer gyorsabb volt a két világháború közötti negyedszázadhoz képest.

Az 1970-es, 1980-as évek fordulójától azonban megjelent a globalizáció, egy új világgazdasági kapcsolatrendszer, egyben egy deregulált szabadkereskedelmi rendszer a neoliberalizmus gazdaságpolitikájának jegyében. Mindez összekapcsolódott egy új technikai forradalommal és a multinacionális vállalatok hihetetlenül gyors felemelkedésével. A 21. század elejére a multinacionális 
vállalatok állították elő a világ gyáripari termelésének háromnegyedét. Majdnem egymillió bedolgozó alvállalat szőtte át az európai tagországokat, vagyis egy nagyon erős 'európaizáció' indult meg a gazdaságban. Ugyanakkor a neoliberális globalizáció, ami minden kontrollt le kívánt bontani, az Egyesült Államok, Japán, majd az ún. Kis Tigrisek ázsiai országainak erőteljes versenyét hozta a világgazdaságra, és Európa piacainak hihetetlen nagy részét hasította le. Európa védekezésre kényszerült, úgymond a globalizáció ellen a regionalizáció útjára lépett és egy fejlesztési modellváltást hajtott végre: a háború után követett extenzív növekedési modellt, ami az amerikai technológia importjára épült, egy intenzív modellel váltotta fel, ami saját kutatásra és innovációra épült és elindította Európát a követő státuszból a versenyképesség útján. Ez az európaiasodás azzal is járt, hogy az európai multinacionális vállalatok részben visszavonultak a világgazdaságból, jó példa erre a világ egyik első multinacionális vállalata, a hollandangol tulajdonú Unilever, amely hetven Európán kívüli alvállalatát adta el és fordult az európai piachoz. Németország addigi külföldi tőkebefektetéseit 40\%-ban Európán kívül hajtotta végre, ezt leépítette 17\%-ra és ugyancsak Európa felé fordult.

Az integráció hihetetlen gazdasági következményekkel járt. Rengeteg, önmagában nem mérhető előnyről lehet beszélni: az összeurópai terméksztenderdek bevezetése (ami szabad értékesítést tett lehetővé, hiszen ehhez nem lett volna elég csak a vámok lebontása), a határokon átívelő fúziós rendszerek (ami „összeolvasztotta” az országok gazdaságát), egy harmonizált jogrend (amit Csaba László intézménytranszfernek nevez), az áruk, a tőke és az emberek szabad áramlása. Mindez a különböző számítások szerint 5-20\% többletnövekedést hozott a tagországok számára. Azért ilyen széles a skála, mert jól ismert, hogy van hat ország, amely már 1958-tól részt vett ebben az integrációban, míg a dél-európai országok csak az 1980-as években, a közép-európai országok csak 2004-ben, 2007-ben és 2013-ban csatlakoztak.

Ami hihetetlen növekedésgyorsító volt az egész integrációs rendszerben, az a közvetlen külföldi befektetések ugrásszerü növekedése: 1970-ben ez 5 milliárd dollárt tett ki, 2007-ben 857 milliárd dollárt, tehát „elöntötte” Európát. 43000 vállalati fúzió zajlott le csak az ezredforduló körüli években, ami a világ fúzióinak kétharmada. Itt egy áttörésről beszélhetünk: a nagy európai vállalatok bevételének kétharmada ekkorra már nem nemzeti, hanem európai piacról származott, és a belső európai árukereskedelem csupán az ezredforduló utáni kb. másfél évtizedben is több mint megkétszereződött. Az Európai Unió tagországai ezzel a világ legintegrálódottabb egységét hozták létre mind az észak- és dél-amerikai, mind az ázsiai és csendes-óceáni régióval szemben.

Mindeközben az Európai Unió egy jóléti rendszer létrehozását és elterjesztését is segítette. Az ún. emberi fejlettségi index (HDI) azt mutatja, hogy Amerikához képest Nyugat-Európa, sőt, Dél- és Közép-Európa is felzárkózott, mert az európai régióban a jóléti rendszer sokkal erőteljesebb, mint az USA-ban, s emiatt magasabb az átlagos élettartam, nagyobb az iskolában eltöltött évek száma, jóval nagyobb a szociális kiadások aránya a nemzeti jövedelemhez viszonyítva és jóval egyenlőbb a jövedelem eloszlása, amit a GINI-indexek világosan mutatnak. Ez az egyenlőbb jövedelemelosztás nagy előnye az Európai Uniónak mind Amerikához, mind a nem uniós európai országokhoz képest.

Azt is fontos kiemelni, hogy az unió közös előnyöket biztosít minden tagország számára, de ezzel különleges lehetőséget nyújt a kevésbé fejlett tagországok felzárkózására. A mediterrán régió és Írország erre a legszemléletesebb példa: a csatlakozás előtt Nyugat-Európa egy före jutó GDP-jének 50\%-át alig haladták meg, 2019-ben pedig már a 75\%-át is elérték, tehát sokkal gyorsabban fejlődtek. Míg NyugatEurópa nagyjából megkétszerezte a jövedelmét 1973 és 2014 között, a mediterrán országok megnégyszerezték, Írország pedig majdnem megnyolcszorozta. 
Kelet-Közép-Európa is elindult a felzárkózás útján. Az adatok egyértelműen mutatják, hogy KözépEurópa és a Baltikum mennyivel gyorsabban növekedett, mint az Európai Unión kívül maradt orosz, török és balkáni világ. Az unióhoz való csatlakozás megfordította Közép-Európa egész fejlődési útját. 1870-től, amikor Közép-Európa Nyugat-Európa jövedelmi szintjének 54 százalékán állt, állandó hanyatlás volt megfigyelhetö. A mélypont 2000-re jött el, amikor a korábbi 54 százalékkal szemben már csak a nyugateurópai jövedelmi szint 23 százalékát érte el Közép-Európa. A fordulat 2000 után következett be, melynek eredményeként 23 százalékról 2019-re 36 százalékra nőtt a közép-európai és baltikumi relatív jövedelemszint Nyugat-Európához képest.

Befejezésként hadd említsem további részletek nélkül, hogy Európa elindult a régi gazdasági szuperhatalmi pozíciójának visszahódítása útján. Az Európai Unió alapító országai majdnem négyszeresre növelték gazdasági erejüket csak a 20. század második felében, míg az USA, Kanada, Ausztrália, Új-Zéland alig több mint megkétszerezte. Az eurózónához tartozó 19 tagország egy före jutó jövedelme eléri az amerikai szint majdnem háromnegyedét, de az európai jövedelemszint bizonyos értelemben nemcsak megközelíti, hanem el is éri az amerikait, ha figyelembe vesszük, hogy a jóléti rendszer miatt Európa lakossága összességében mintegy 20-25 százalékkal kevesebbet dolgozik, mint Amerikában, ahol nincs jóléti állam. Az adatok azt is megmutatják, hogy a világkereskedelemben az Európai Unió majdnem kétszer akkora súllyal bír, mint az Egyesült Államok. Az európai integráció tehát gazdasági szuperhatalommá emeli az Európai Uniót és annak tagországait.

Nagyon köszönöm figyelmeteket!

\section{Geoffrey Hodgson elöadásának összefoglalása:}

Geoffrey Hodgson, a Loughborough Egyetem londoni campusának professzora Finance, Capital and the Mystery of Economic Development címmel tartott előadást a konferencia angol nyelvü szekciójában. Előadásának kiindulópontja, hogy a kapitalizmus „szótári” definíciójánál két fő tulajdonságot említenek: a termelőeszközök magántulajdonát és a piacok meghatározó szerepét. Ezek valóban fontos tulajdonságai egy kapitalista rendszernek, azonban mind a magántulajdon, mind a piac évezredek óta létezik. Mondhatjuk ez alapján, hogy a kapitalizmus is évezredek óta létező rendszer? Természetesen nem, viszont ebből az következik, hogy a kapitalista rendszer pontosabb definíciójára van szükség.

A hosszú idősoros adatok azt mutatják, hogy a mai fejlett kapitalista országok - a korábbi évszázadok stagnálását követően - 1800 környékén indultak robbanásszerü gazdasági fejlődésnek. Az egy főre jutó GDP világszinten mintegy tizenegyszeresre, Nyugat-Európában pedig húszszorosra nőtt 1700 és 2003 között. Erre, a gazdasági növekedés megindulását követő, modern korszakra tarthatjuk fent a kapitalista rendszer fogalmát. A fő kérdés egyrészt az, hogy minek volt köszönhető ez a meginduló gazdasági fejlődés, másreszt pedig az, hogy melyek e gazdasági rendszer fö jellemzői.

A gazdasági növekedés megindulásának egyik fő mozgatórugója mindenképpen a technológiai fejlődés, az ipari forradalom volt, annak számtalan új találmányával a gőzgéptől és a vasúttól a távíróig. Ez a technológiai fejlődés hatalmas termelékenység-növekedést eredményezett. Az új ötletek, találmányok megjelenése kulcsfontosságú, azonban a teljes kép megértéséhez azt is tisztázni kell, hogy ez maga milyen tényezőknek köszönhető. A technológiai fejlődéshez elengedhetetlen, hogy a minket körülvevő világot tanulmányozó emberek szabadon megoszthassák egymással eredményeiket, ötleteiket. Ehhez feltétlenül szükséges a gondolkodás szabadsága, vagyis egy olyan politikai intézményrendszer, ami nem elnyomja, hanem támogatja a világ megismerésére törekvő embereket. A technológiai, és így a gazdasági fejlődés 
magyarázatát tehát a 17-18. századi Nyugat-Európában bekövetkező intézményi változásokban kell keresnünk.

A politikai intézményrendszer megváltozása mellett a kapitalista fejlődés megindulása szempontjából kiemelkedő szerepe van az új pénzügyi intézmények (bankok, jelzálog, tőzsde stb.) megjelenésének is, annak ellenére, hogy a történettudomány sokáig alábecsülte a pénzügyi intézmények szerepét a brit ipari forradalomban. A hagyományos megközelítés szerint az ipari forradalom és a gyáripar úttörői többnyire saját megtakarításaikra és közvetlen barátaik, családtagjaik támogatására támaszkodtak, azonban az empirikus tapasztalatok ezt nem támasztják alá. Az ipari termelés fejlődéséhez elengedhetetlen volt a hitelezés fellendülése, azon belül a jelzálog intézményének megjelenése és elterjedése. A pénzügyi intézmények és a kapcsolódó jogi keretek fejlődése elválaszthatatlan a gazdasági teljesítmény alakulásától, például a pénzügyi intézményrendszer 1770-1820 közötti lassabb fejlödése is hozzájárult ahhoz, hogy a gazdasági növekedés ebben az időszakban lényegesen lassabb volt, mint a rákövetkező fél évszázadban.

A kapitalista gazdasági fejlődés magyarázatában és a kapitalista rendszer jellemzői tekintetében tehát egyaránt megkerülhetetlen a pénzügyi intézmények szerepe. Ennek a gazdaságtörténeti vonatkozásokon túl a fejlődő országok mai növekedési potenciálja tekintetében is nagy jelentősége van.

Németh András Olivér ${ }^{2}$

\footnotetext{
${ }^{2}$ egyetemi adjunktus, Budapesti Corvinus Egyetem, Gazdaság- és Közpolitika Intézet, Gazdaságpolitika és Munkagazdaságtan Tanszék 